\title{
Rarity as a criterion for endangerment in Florida's fauna
}

\author{
Russell L. Burke and Stephen R. Humphrey
}

It has been argued that the initial rarity of an animal species may be a good indicator of subsequent vulnerability. The usefulness of this argument in the conservation of endangered species has been investigated by the authors, who have compared the apparent vulnerability of certain rare animals with their actual status. The two approaches agreed substantially, but some striking differences occurred. Some rare species seem more prone to extinction than is officially recognized, and their status should be reviewed. Other species are not particularly rare, but are threatened for other biological and economic reasons. Knowledge of rarity is a good starting point, but this sould be followed by a detailed examination of other relevant factors to discern genuine risk.

Consideration of life history characteristics and extinctions of birds from land-bridge islands and fragmented forests (Terborgh, 1974; Terborgh and Winter, 1980) has led to the inference that the single best indicator of vulnerability is the initial rarity of the animal. The former paper considered certain life history characteristics to be unstable: specialization at high trophic levels; being the largest member of a feeding guild; having weak dispersing and colonizing ability; being endemic; nesting colonially; and migrating. The latter paper found that most of these traits caused animals to be rare, which in turn was believed to predispose them to extinction. The manifestation of initial rarity is that an animal is either very limited in distribution, or widespread but quite uncommon locally.

How useful is this essentially theoretical perspective in the pragmatic business of listing and recovering endangered species? To test this question, we compared apparent vulnerability with management-agency designations across a sample fauna: the reptiles, amphibians and mammals of Florida. This is an exemplary test fauna because of an optimal combination of features. Firstly, the extremely rapid growth of Florida's human population raises the scale of endangerment of native biota and does so Endangerment in Florida's fauna according to a settlement pattern independent of species' biology. Secondly, the survival status of the fauna is unusually well documented because an active community of natural-resource scholars is supported by government and academia. Thirdly, the fauna is relatively well known taxonomically, even to the subspecies level. And finally, the fauna shows an extremely high degree of endemism-the outcome of elaborate adaptive radiations promoted by Florida's unique history and geography. The State consists of a long peninsula, bordered by barrier islands, and attenuates in a long archipelago, all extending along a gradient from a warm-temperate, continental climate to a subtropical, maritime one. Other areas of the world have an equally interesting geography or more diverse faunas, but few combine this with the urgency of rapid habitat loss and the judgment possible with strong bases of taxonomic and ecological knowledge.

\section{Legal status/rating rarity}

The survival status of Florida vertebrates believed to be in danger of exinction has been formally designated by both Federal and State governments. Our comparisons are with these designations (Florida Game and Fresh Water Fish 
Commission, 1985; US Fish and Wildlife Service, 1985). The USFWS list is widely recognized and tends to change slowly because of complicated listing processes. The FGFWFC list is less well known but better reflects local conditions. Both agencies define 'endangered' as being in immediate danger of extinction or extirpation, and 'threatened' as being acutely vulnerable or declining in number or range and very likely to become endangered. USFWS recognizes candidates for listing as 'under review.' In contrast, FGFWFC acts quickly to make official listings, and species not qualifying under the primary definitions are designated 'species of special concern' when a lesser problem exists, for example: (1) significant vulnerability that may lead to threatened status, (2) possibly threatened but confirmation needed, (3) a keystone species, the decline of which would affect other species, or (4) insufficiently recovered from historical population depletion.

To evaluate vulnerability according to initial rarity, it was necessary to organize Terborgh's factors into a hierarchy of qualitative criteria, emphasizing the most important. We summarized the primary indications of rarity as limited distribution, low local density, and large body size. We awarded an animal one point for each of these characteristics it possesses, or two if the condition is extreme. Additionally, we compiled other sensitive factors under a fourth category, but did not award any points for them. Details of point awarding varied by taxon; for other applications, criteria may need to be modified to accomodate various geographic units. Some examples follow. Initial screening of reptile and amphibian species was by geographic range. Any not principally Floridian (with 50 per cent or more of their entire range within the State) were removed from the list. Of the remainder, 'rare' species had ranges of 10-25 per cent of the State, and 'exceedingly rare' species occurred in less than 10 per cent of the State. The absolute numbers are important only when results from this ranking system are to be compared with those of another system. Relative densities were estimated from our field experience, supplemented by other specialists as needed. 'Large body size' was designated for species that are exceptionally large for their 98 taxon-for example, the largest 20 per cent of snake species. The largest species in each higher taxon and any other exceptionally large forms, such as marine turtles, were awarded two points.

To summarize these ratings in a way roughly comparable to the conventional endangered and threatened designations, we assigned animals with four or more points to an 'extremely vulnerable' category. Those with three points were considered 'very vulnerable', and those with two points plus some other sensitive factors were considered 'moderately vulnerable'. Animals not thus rated but legally listed were placed in a miscellaneous category termed 'possibly vulnerable'. The tabular details upon which this summary is based are available from the authors by request. All native species and subspecies were considered. Taxonomy followed Conant (1975) for reptiles and amphibians and Hall (1981) for mammals, except where newer information was available.

\section{The comparisons}

Comparisons of vulnerability ratings with legal listings (Tables 1 and 2) showed general concordance. Most of the animals ranked as extremely or very vulnerable are listed as endangered or threatened. However, two subsets deviated from this pattern, appearing as mismatches of our vulnerability ratings from the legal listings. One included vulnerable animals that are not officially considered endangered or threatened. A few, like the South Florida rainbow snake, were rated as extremely vulnerable; most appeared in the very or moderately vulnerable categories. At least some of these animals are genuinely at risk - the pallid beach mouse was reported as apparently extinct (Humphrey and Barbour, 1981) before it was listed by either FGFWFC or USFWS. In contrast, some other animals were rated as less vulnerable than their legal status would suggest. We were unable to reduce the scale of these discordances by tinkering with our definitions of vulnerability. Examples such as the Perdido Key and Choctawatchee beach mice are in fact highly endangered, so this trend apparently shows inadequacy in some vulnerability ratings.

Oryx Vol 21 No 2, April 1987 
Table 1. Comparison of reptile and amphibian vulnerability with legal status

\begin{tabular}{lll}
\hline Degree of vulnerability (this study) & Legal status (FGFWFC) & Legal status (USF \\
\hline Category I-extremely vulnerable & & \\
American crocodile, Crocodylus acutus & Endangered & Endangered \\
Barbour's map turtle, Graptemys barbouri & Special concern & Under review \\
Atlantic green turtle, Chelonia m. mydas & Endangered & Threatened \\
Atlantic hawksbill, Eretmochelys $i$. imbricata & Endangered & Endangered \\
Atlantic loggerhead, Caretta c. caretta & Threatened & Threatened \\
Atlantic ridley, Lepidochelys kempi & Endangered & Endangered \\
Atlantic leatherback, Dermochelys c. coriacea & Endangered & Endangered \\
South Florida rainbow snake, Farancia erythrogramma seminola & Not listed & Not listed \\
Short-tailed snake, Stilsoma extenuatum & Threatened & Under review \\
Rimrock crowned snake, Tantilla oolitica & Threatened & Under review \\
Florida bog frog, Rana okaloosae & Special concern & Not listed \\
Gulf Hammock dwarf siren, Pseudobranchus striatus lustricolus & Not listed & Under review
\end{tabular}

\section{Category II-very vulnerable}

Key mud turtle, Kinostemon bauri palmarum

Mangrove terrapin, Malaclemys terrapin rhizophorarum

Suwannee cooter, Chrysemys concinna suwanniensis

Florida bark anole, Anolis distichus floridanus

Florida scrub lizard, Sceloporus woodi

Florida Keys mole skink, Eumeces egregius egregius

Cedar Key mole skink, Eumeces egregius onocrepis

Blue-tailed mole skink, Eumeces egregius lividus

Sand skink, Neoseps reynoldsi

Atlantic saltmarsh snake, Nerodia fasciata taeniata

Key ringneck snake, Diadophis punctatus acricus

Brown-chinned racer, Coluber constrictor helvigularis

Everglades racer, Coluber constrictor paludicola

Eastern indigo snake, Drymarchon c. corias

Everglades rat snake, Elaphe obsoleta rossalleni

Key rat snake, Elaphe obsoleta deckerti

Gulf Hammock rat snake, Elaphe obsoleta williamsi

Striped newt, Notophthalmus perstriatus

$\begin{array}{ll}\text { Endangered } & \text { Under review } \\ \text { Not listed } & \text { Not listed } \\ \text { Special concern } & \text { Under review } \\ \text { Not listed } & \text { Not listed } \\ \text { Not listed } & \text { Under review } \\ \text { Special concern } & \text { Under review } \\ \text { Not listed } & \text { Not listed } \\ \text { Threatened } & \text { Under review } \\ \text { Threatened } & \text { Under review } \\ \text { Threatened } & \text { Threatened } \\ \text { Threatened } & \text { Under review } \\ \text { Not listed } & \text { Not listed } \\ \text { Not listed } & \text { Not listed } \\ \text { Threatened } & \text { Threatened } \\ \text { Not listed } & \text { Not listed } \\ \text { Not listed } & \text { Not listed } \\ \text { Not listed } & \text { Not listed } \\ \text { Not listed } & \text { Not listed }\end{array}$

\section{Category III-moderately vulnerable}

Florida East Coast terrapin, Malaclemys terrapin tequesta

Ornate diamondback terrapin, Malaclemys terrapin macrospilota

Reef gecko, Sphaerodactylus n. notatus

Gulf saltmarsh snake, Nerodia fasciata clarki

Mangrove water snake, Nerodia fasciata compressicauda

Blue-striped garter snake, Thamnophis sirtalis similis

Blue-striped ribbon snake, Thamnophis sauritus sauritis

Florida pine snake, Pituophis melanoleucas mugitis

Rosy rat snake, Elaphe guttata rosacea

Florida crowned snake, Tantilla relicta neilli

Peninsula crowned snake, Tantilla $r$. relicta

Costal dunes crowned snake, Tantilla relicta pamlica

Not listed

Not listed

Not listed

Not listed

Not listed

Not listed

Not listed

Special concern

Special concern

Not listed

Not listed

Not listed

Threatened

Special Concern

Special concern

Not listed

Special concern

Special concern
Not listed

Not listed

Not listed

Not listed

Not listed

Not listed

Not listed

Under review

Not listed

Not listed

Not listed

Not listed

Threatened

Under review

Under review

Under review

Under review

Under review 

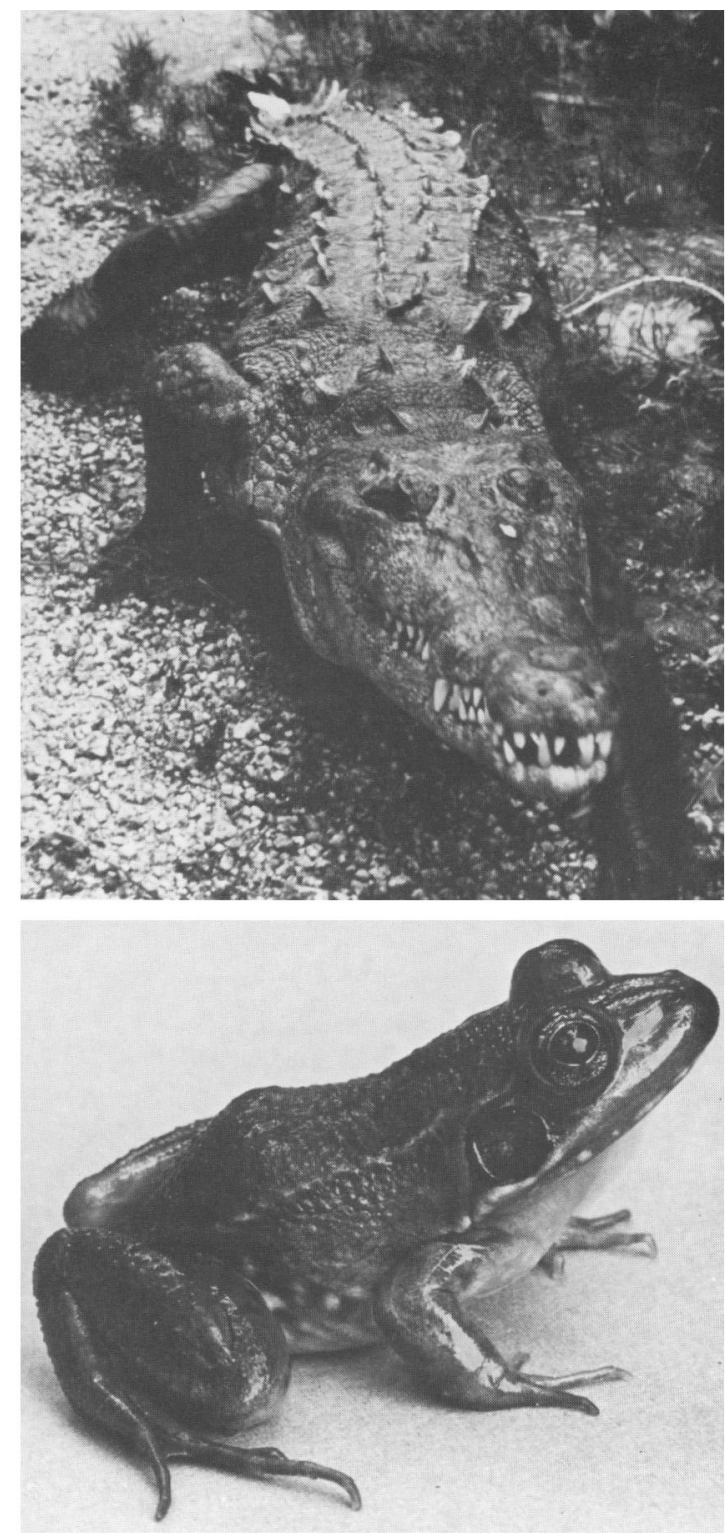

\section{Rare animals may or may not be in trouble}

Absence of certain vulnerable animals from the official list shows that some may be more prone to extinction than is currently recognized. These taxa should be carefully scrutinized as candidates for listing. Some of the unlisted beach mouse subspecies may even be endangered. 100

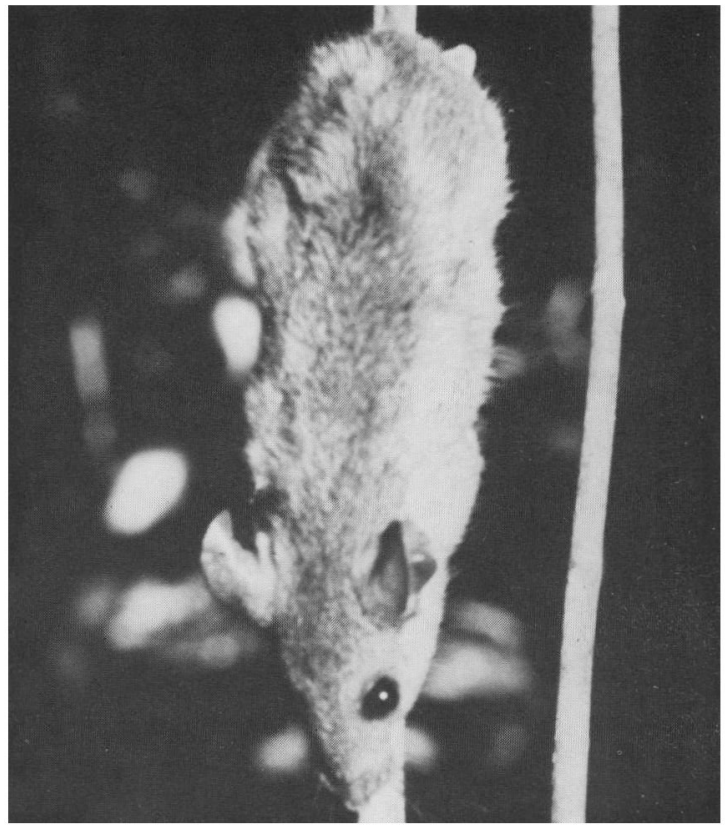

Above left: A small population of American crocodiles persists in southern Florida, but has not responded as well to protection as the American alligator (Stephen R. Humphrey).

Above: The Key Largo cotton mouse is endemic to the largest patch of unprotected tropical hardwood forest in the US east of Hawaii (Stephen R. Humphrey).

Below: The Florida bog frog is newly discovered and has an extremely limited distribution (Barry W. Mansell).

Failure of our ratings to detect obvious endangerment of other taxa shows the importance of life history characteristics other than rarity, and of the realities of human use of natural resources. In many cases, the key factor is an extraordinary concentration of human settlement within the range of an animal. In the case of the grey bat, the concept of initial rarity simply does not apply. This species is very abundant where it occurs, but it bears young in uncommon sites (caves) with a narrow microclimatic requirement, and it does not tolerate intrusion of spelunkers or scientists in these sites.

Two conclusions show that knowledge of rarity is necessary, but not nearly sufficient, to evaluate the risk of extinction. Firstly, inherent rarity is an important initial consideration. Some vulnerable species have been overlooked because their rarity was not appreciated, and this error should

Oryx Vol 21 No 2, April 1987 
be remedied. Secondly, the log-normal distribution of the abundance of species (Preston, 1948; Fisher, 1952; Williams, 1953) ensures that most species are rare as a fact of life. While these rare species may be considered at risk in a statistical sense (Terborgh's point), only some are

Table 2. Comparison of mammal vulnerability with legal status

Degree of vulnerability (this study)

\section{Category I-extremely vulnerable}

Sperm whale, Physeter catodon

Sei whale, Balaenoptera borealis

Fin-backed whale, Balaenoptera physalus

Hump-bàcked whale, Megaptera novaeangliae

Northern right whale, Balaena glacialis

Florida black bear, Ursus americanus floridanus

Florida panther, Felis concolor coryi

West Indian manatee, Trichechus manatus latirostris

\section{Category II - very vulnerable}

Florida mastiff bat, Eumops glaucinus floridanus

Big Cypress fox squirrel, Sciurus niger avicennia

Goff's pocket gopher, Geomys pinetis goffi

Silver rice rat, Oryzomys argentatus

Key deer, Odocoileus virginianus clavium

\section{Category III-moderately vulnerable}

Anastasia Island mole, Scalopus aquaticus anastasae

Bass' eastern mole, Scalopus aquaticus bassi

Small eastern mole, Scalopus aquaticus parvus

Gold Coast eastern mole, Scalopus aquaticus porteri

Indiana bat, Myotis sodalis

Grey bat, Myotis grisescens

Key marsh rabbit, Sylvilagus palustris hefneri

Micco cottontail, Sylvilagus floridanus ammophilus

Gold Coast cottontail, Sylvilagus floridanus paulsoni

Sherman's fox squirrel, Sciurus niger shermani

Pine Island rice rat, Oryzomys palustris planirostris

Sanibel Island rice rat, Oryzomys palustris sanibeli

Choctawhatchee beach mouse, Peromyscus polionotus allophrys

Pallid beach mouse, Peromyscus polionotus decoloratus

Santa Rosa Island beach mouse, Peromyscus polionotus leucocephalus

Southeastern beach mouse, Peromyscus polionotus niveiventris

Peninsular beach mouse, Peromyscus polionotus peninsularis

Anastasia Island beach mouse, Peromyscus polionotus phasma

Perdido Key beach mouse, Peromyscus polionotus trissyllespis

Key Largo cotton mouse, Peromyscus gossypinus allapticola

Chadwick cotton mouse, Peromyscus gossypinus restrictus

Key Largo woodrat, Neotoma floridana smalli

Everglades mink, Mustela vison evergladensis

\section{Category IV-possibly vulnerable}

Homosassa shrew, Sorex longirostris eionis

Sherman's short-tailed shrew, Blarina carolinensis shermani

Eastern chipmunk, Tamias striatus

Florida mouse, Peromyscus floridanus

Saltmarsh meadow vole, Microtus pennsylvanicus

dukecampbelli

Key Vaca raccoon, Procyon lotor auspicatus

Legal status (FGFWFC) Legal status (USFWS)

Endangered

Endangered

Endangered

Endangered

Endangered

Threatened

Endangered

Endangered

Not listed

Threatened

Endangered $t$

Endangered

Threatened

Not listed

Not listed

Not listed

Not listed

Endangered

Endangered

Not listed

Not listed

Not listed

Special concern

Not listed

Special concern

Endangered

Endangered $\dagger$

Not listed

Not listed

Not listed

Not listed

Endangered

Endangered

Special concern $\div$

Endangered

Threatened

Special concern

Special concern

Special concern

Special concern

Special concern

Threatened
Endangered

Endangered

Endangered

Endangered

Endangered

Under review

Endangered

Endangered

Under review

Under review

Under review ${ }^{\dagger}$

Under review

Endangered

Under review

Under review

Not listed

Not listed

Endangered

Endangered

Under review

Under review

Not listed

Under review

Under review

Under review

Endangered

Under review ${ }^{\dagger}$

Under review

Under review

Under review

Under review

Endangered

Endangered

Under review $\dagger$

Endangered

Under review

Under review

Under review

Not listed

Under review

Under review

Under review

*Except in three areas where hunting is permitted. †Actual status is apparently extinct. 


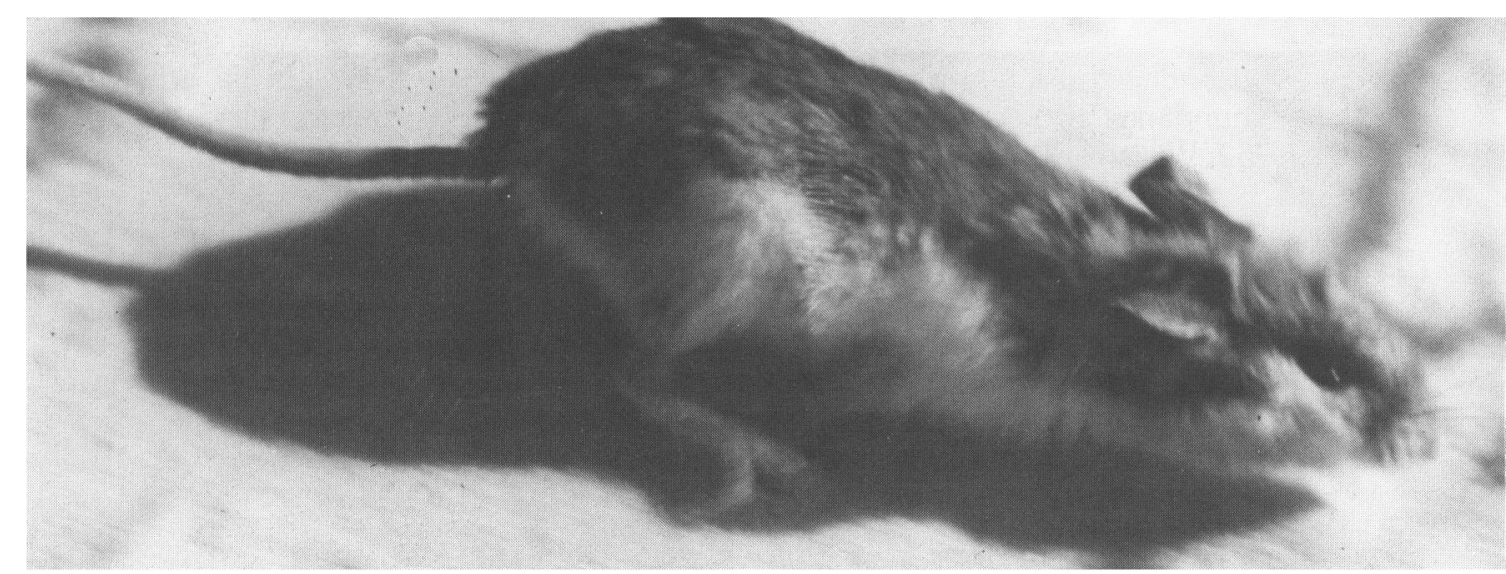

Choctawatchee beach mouse running for its life. There are two remnants of the original range: one is protected and the other is slated for development (Stephen R. Humphrey).

actually threatened. Therefore, there is no substitute for the conventional subjective evaluation, in which all relevant factors are considered. For example, coastal islands in Florida both promote endemism and attract human settlement, but other types of habitat islands may do only the former.

So many biological and economic factors can affect a species's vulnerability that applying an exhaustive ranking system to all species is impractical. We recommend that an early step in considering priorities for the conservation of endangered species be the application of an easyto-use, rarity-based filter such as ours to highlight species needing detailed attention. Then, those species should be subjected to a much more meticulous examination of life history and trends in habitat and population. No ranking system can be devised to be completely objective, because the choice and weighting of various factors is necessarily subjective (for example, Sparrowe and Wight, 1975). The best overall approach may be to compare the results from multiple screening techniques. Species repeatedly emerging as being in danger should be listed, and anomalous results should be examined critically.

\section{Acknowledgments}

We thank Bettina Sparrowe and Don A. Wood for sharing ideas on the degrees of endangerment, Paul E. Moler and Peter A. Meylan for valuable background information on reptiles and amphibians, John G. Robinson for stimulating an early version of this manuscript, and an anonymous reviewer for incisive and constructive comments.

102

\section{References}

Conant, R. 1975. A Field Guide to Reptiles and Amphibians of Eastem and Central North America, 2nd edition. Houghton Mifflin Co., Boston.

Fisher, J. 1952. Bird numbers: a discussion of the breeding population of inland birds of England and Wales. South Eastem Naturalist, 57, 1-10.

Florida Game and Fresh Water Fish Commission. 1985 Official Lists of Endangered and Potentially Endangered Fauna and Flora in Florida. Tallahassee, Florida.

Hall, E.R. 1981. The Mammals of North America, 2nd edition. John Wiley \& Sons, New York.

Humphrey, S.R. and Barbour, D.B. 1981. Status and habitat of three subspecies of Peromyscus polionotus in Florida. $J$. Mammal. 60, 840-844.

Preston, F.W. 1948. The commonness, and rarity, of animals. Ecology, 29, 620-624.

Sparrowe, R.D. and Wight, H.M. 1975. Setting priorities for the Endangered Species Program. Transactions of the 40th North American Wildlife and Natural Resources Conference, pp. 142-156.

US Fish and Wildlife Service. 1985. Endangered and threatened wildlife and plants; review of vertebrate wildife; notice of review. Federal Register, 50, 37,958 37,967

Terborgh, J. 1974. Preservation of natural diversity: the problem of extinction prone species. Bioscience, 24, 715722.

Terborgh, J. and Winter, B. 1980. Some causes of extinction. In Conservation Biology: An Evolutionary-Ecological Perspective (Eds M. E. Soule and B. A. Wilcox), pp. 119-133. Sinauer Associates Inc., Sunderland, Massachusetts.

Williams, C.B. 1953. The relative abundance of different species in a wild animal population. J. Animal Ecol. 22, $14-31$.

Russell L. Burke, Department of Wildilife and Range Sciences, School of Forest Resources and Conservation, University of Florida, Gainesville, FL 32611, USA.

Stephen R. Humphrey, Florida State Museum, Universtiy of Florida, Gainesville, FL 32611, USA.

Oryx Vol 21 No 2, April 1987 